\title{
Investing in New Crop Varieties
}

ISSN: 2637-7659

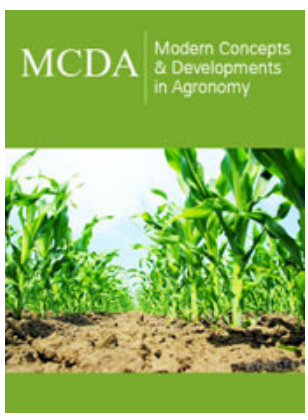

*Corresponding author: Andrew Schmitz, Eminent Scholar and Professor, 1130-B McCarty Hall, PO Box, 110240, Gainesville, FL 32611, University of Florida, USA

Submission: May 08, 2020

Published: 眥 May 14, 2020

Volume 6 - Issue 2

How to cite this article: Andrew Schmitz. InvestinginNewCropVarieties.ModConcep Dev Agrono. 6(2). MCDA. 000633. 2020. DOI: 10.31031/MCDA.2020.06.000633

Copyright@ Andrew Schmitz, This article is distributed under the terms of the Creative Commons Attribution 4.0 International License, which permits unrestricted use and redistribution provided that the original author and source are credited.

\author{
Andrew Schmitz* \\ University of Florida, USA
}

\section{Opinion}

\section{Introduction}

Economists continue to estimate the rate of return from public investment in the development of new crop varieties. The returns from new crop varieties have been impressive, as shown in Table 1 [1]. Take, for example, the pioneering work of Griliches [2], where the rate of return on public investment in the development of new U.S. corn varieties was approximately $4 \%$ [2]. In addition, the adoption of genetically modified soybeans, maize, and cotton, increased yields by more than $20 \%$ and reduced pesticide use and cost by $30 \%$ (e.g., Bt cotton contributed to the fast adoption of Bt cotton in India) [3].

Table 1: Selected economic returns to agricultural research.

\begin{tabular}{|c|c|c|c|}
\hline Commodity & Study & Rate of Return (\%) & Country \\
\hline Aggregate Agriculture & Evenson et al. (1979) & 65 & United States \\
\hline Barley & Ulrich et al. (1986) & $31-75^{\text {a }}$ & Canada \\
\hline Canola & Ulrich et al. (1984) & 51 & Canada \\
\hline Hybrid Corn & Griliches [2] & $35-40$ & Colombia \\
\hline Rice & $\begin{array}{c}\text { Scobie and Posada } \\
(1978)\end{array}$ & United States \\
\hline Tomatoes & $\begin{array}{c}\text { Schmitz and Seckler } \\
(1970)\end{array}$ & Canada \\
\hline Wheat & $\begin{array}{c}\text { Zentner and Peterson } \\
(1984)\end{array}$ & 38 & Source \\
\hline
\end{tabular}

\section{Factors affecting crop yields}

Many of the studies on rates of return to public investment focus on the development of new crop varieties. Crop yields are affected not only by new varietal development, but also by the use of fertilizers, pesticides, herbicides, crop rotation choice, and mechanization (including machines for planting and harvesting).

\section{Mechanization}

Improved mechanization from planting to harvest has changed dramatically over the past fifty years [4]. Mechanization plays a major role in crop yield improvements. For example, in Florida, over $20 \%$ of the increase in sugarcane yields is a result of improved mechanization, especially in harvesting the crop [5]. Similar results have been noted for sugarcane yields in Louisiana [6]. Another example is the dramatic change in the types of crops grown in the Prairie region of Canada, along with the increase in total planted acreage. Thirty years ago, wheat and barley were the primary crops grown on the Prairies. Today, they are minor crops compared to canola, lentils, and peas. These crops are made possible because of investment in varietal development and in planting and harvesting technologies such as air drills and straight header combines [4]. Also, the development of continuous crop technologies keeps more cropland actively producing year-round, where before, at least $30 \%$ of the land was left fallow each year. 


\section{Private investment in research and development}

The private sector invests heavily in research and development, both internally and in partnership with public institutions, including universities. Monies spent for research and development by the private sector exceed that of the public sector, especially for farm equipment and new crop varieties. For example, the private sector developed the majority of new varieties of genetically modified seeds for crops such as canola. Roundup Ready canola was developed by Monsanto, and In Vigor canola was developed by Bayer for tolerance to a specific herbicide. Millions of acres of genetically modified canola are planted every year. Another example is genetically modified sugar beets, which have been genetically engineered using biotechnology to directly modify the genome [7]. Roundup Ready sugar beets developed by Monsanto make up most of the commercial sugar beet production in the United States. Biotechnology has greatly increased crop yields [3].

\section{Crop yields and input use}

Crop yields differ greatly by country and by the management capabilities of farm operators. Optimal timing is crucial for the application of pesticides, herbicides, and fertilizers. For example, yield response of crops to fertilizer application is significant. Generally, crop yields are lower in developing countries than in developed countries $[8,9]$. This is in part due to lack of soil testing and low rates of fertilizer applications.

\section{Learning by doing}

Little literature exists on the impact of "learning by doing" by individual farmers on agricultural productivity. For example, optimal crop rotations are a necessity for successful farming, and the choice changes over time are dependent, at least partly, on the learning by doing of the farm operator. This is also the case for optimal timing of the application of herbicides and pesticides. Soil testing also fits this category.

\section{Double cropping and joint enterprises}

Considerable crop acreage is double-cropped worldwide, where two crops are grown on the same field within a given year. For example, farmers in Brazil double crop sugarcane and wheat, while U.S. farmers in Missouri double crop soybeans and wheat. The double-cropping system serves two purposes: environmental and economic, such as controlling soil erosion while increasing farmers' cash flow [10]. Another example of double-cropping systems is joint enterprises, such as in Louisiana, where rice grows in conjunction with crawfish. In the case of rice, new varietal development for rice possibly has an impact on crawfish yields; for example, improvements in rice yields may positively affect the profitability of crawfish production.

\section{Conclusion}

Future work on the estimation of the rate of return to research should expand the scope of the framework used by past researchers to include the factors above.

\section{References}

1. Schmitz A, Moss CB, Schmitz TG, van Kooten GC, Schmitz HC (2020) Food and agricultural policies: Trade, agribusiness, and rent-seeking behaviour, ( $3^{\text {rd }}$ Edn). University of Toronto Press, Toronto, USA.

2. Griliches Z (1957) Hybrid corn: an exploration in the economics of technological change. Econometrica 25(4): 501-522.

3. Zilberman D, Wesseler J, Schmitz A, Gordon B (2019) Economics of agricultural biotechnology. In: Cramer GL, Paudel KP, Schmitz A (Eds.), The Routledge Handbook of Agricultural Economics. Routledge, London, pp. 670-686.

4. Schmitz A, Moss CB (2015) Mechanized agriculture: machine adoption, farm size, and labor displacement. AgBioForum 18(3): 278296.

5. Schmitz A, Zhang F (2019) The dynamics of sugarcane and sugar yields in Florida: 1950-2018. Crop Science 59(5): 1880-1886.

6. Schmitz A, Kennedy PL, Zhang F (2020) Sugarcane and sugar yields in Louisiana (1911-2018): varietal development and mechanization. Crop Science (forthcoming).

7. Kennedy PL, Schmitz A, Lewis Delong K (2019) Biotechnology and demand concerns: the case of genetically modified U.S. sugar beets. AgBioForum (in press).

8. Schmitz A, Moss CB (2015) Modelling fertilizer demand: the three bads. In: Schmitz A, Meyers WH (Eds.), Transition to agricultural market economies: the future of Kazakhstan, Russia, and Ukraine. CABI, Wallingford, UK, pp. 157-163.

9. Moss CB, Schmitz A (2019) Distribution of agricultural productivity gains in selected feed the future African countries. Journal of Agribusiness in Developing and Emerging Economics 9(1): 78-90.

10. Pullins EE, Myers RL, Minor HC (2020) Alternative crops in double-crop systems for Missouri. University of Missouri, Missouri, USA. 